\title{
IDENTITY AND THE LEGISLATIVE DECISION MAKING PROCESS: A CASE STUDY OF THE MARYLAND STATE LEGISLATURE ${ }^{1}$
}

\author{
Nadia Brown \\ Saint Louis University
}

Both politicians and the mass public believe that identity influences political behavior. This was clearly seen in the 2008 and 2012 presidential elections as well as Justice Sotomayor's confirmation hearings, during in which the country engaged in conversations about the utility and/ or bias of racial and gendered identities in political decision making. Identity as a factor within political governance was depicted as a prejudice or a narrowing of ideas that produces biases. Signaling that we are not living in a "post racial society," the idea that identity shapes political decision making is most often discussed in respect to those with marginalized identities. Yet White, Protestant, heterosexual, and middleclass males are marked as identity free (Puwar 2004). As a result, the use of identity as a factor in political decision making is frequently relegated and confined to the scholarship on race and ethnicity or women and politics. Identity, however, is salient for all political actors not just minorities and women legislators.

Contrasted with the public discourse around identity's inclusion in politics is scholarship that positively links identity to enriching political discourse. Scholarship on women and minority legislators consistently indicates that member characteristics/group identity influences legislative behavior (Rosenthal 2000; Swers 2002; Mansbridge 1999; Fenno 2003). The inclusion of previously excluded minorities and women into state legislatures over the past forty years has led scholars to examine the legislative influence and impact of minority legislators (Bratton and Haynie, 1999; Smooth 2001, 2006; Fraga et al,. 2005; Tate 1991, 2003; Swain 1993). While the United States has witnessed an increase in the number of women and minority legislators, little is known about the impact of their identity on legislative decision making process.

1 Acknowledgements: Earlier versions of this work were presented at the 2010 National Conference of Black Political Scientists. I would like to thank my colleagues at St. Louis University Christopher Witko, Penny Weis, and Robert Strikwerda for their helpful suggestions on this research. I also appreciate the insightful comments of Alvin Tillery, Danielle Phillips, Anna Mahoney, Bilal Sekou, along with my dissertation committee - Jane Junn, Susan Carroll, Nikol Alexander Floyd, Leela Fernandes, and Wendy Smooth. 
I define identity to include one's somatic indicators, background, life experiences, and social positioning. Identity, for my purposes here, also includes self-affiliation and categorization by others as a member of a racial and gender group. Identity is subject to personal and political interpretation as well as meaning often time resulting in political implications that are not transparent or fixed. While identity is a social construction - socially produced and reproduced, it has strong political and cultural allegiances that make identity a social fact. Identities such as race, gender, class, geographic region, kinship, sexual orientation, nationality, and disability coupled with morals, values, beliefs and traditions are guiding factors that organize the social world (Sanchez, 2006). These social factors comprise one's experiences and form ones identity. "Identities reference our understanding of ourselves in relations to others, they provide their bearers with particular perspective on shared social world" (Alcoff et al., 2006, 97). Identity is distinctly tied to one's experience as "experiences are based on the objective location of people in society. Experiences are rather disguised explanations of social relations and can be evaluated as such" (Alcoff et al., 2006, 4). Thus it is important to both frame identity as more than just one's race or gender as well as include how one's experiences are informed by their race and gender.

In examining the ways in which identity influences legislative decision making, I compare accounts of representation by African American ${ }^{2}$ women and men state legislators as well as White women and men state legislators. Because research has largely focused on race or gender (Simien 2006), I pay specific attention to Black women legislators, who at the intersection of race and gender, employ their race/gender identities in the legislative decision making process. Thus, the term race/gender reflects the political construction of the constitutive racial and gendered identities of Black women as well as the systems and societal structures that are simultaneously raced and gendered. While I focus on Black women and men legislators as well as White women and men legislators, it is likely that other important markers of identity such as other races/ ethnicities, disability, class, generation, sexual orientation, etc. may intersect in meaningful ways for them as well as other legislators.

Intersectionality is an inclusive theory where scholars can take account of multiple, subordinated subject positions such as race, gender, class, ethnicity and language status. Additionally, intersectionality theory purports those relevant categories of difference are mutually constituted both analytically and experientially. Intersectionality helps to

2 Throughout the article I use the terms "Black" and "African American" interchangeably. I capitalized "Black" because "Blacks, like Asians and Latinos, and other 'minorities" constitute a specific cultural group and, as such, require denotation as a proper noun" (Crenshaw, 1988, 1332). 
expand the necessity of descriptive representation, meaning when an elected representative belongs to the same social or demographic group as his or her constituents (Pitkin 1967). "Descriptive representation becomes critical when inherent differences are recognized in terms of identity and shared experiences rather than ideas and opinions" (Phillips 1995, 6). As a result, differences in identity and lived experiences based on social location are strong criteria for descriptive representation. As a result, I am interested in understanding the nuances of identity to locate the ways in which legislators bring identity to bear on legislative decision making.

I pay special attention to the combined racial and gendered identities of legislators to examine if the Maryland state legislators have a nuanced understanding of how the multiplicity of their identities may be included in the legislative decision making process. I include a myriad of empirical examples to illustrate that the influence of identity can be seen in the legislative decision making process. The data shows that many Maryland state legislators include aspects of identity in some factor in legislative decision making. This finding is significant as it illustrates that identity plays a consistent role in legislative decision making as legislators' inclusion of identity does not just appear on voting days or on race or gender specific legislation. Furthermore, unlike previous scholarship on legislative decision making, this essay illustrates that legislators include identity as a factor. I find that Black women Maryland state legislators are more likely to include an intersectional analysis based on race and gender in the legislative decision making process than Black men, White men, and White women legislators. This article offers an intervention into scholars understanding of legislative behavior by arguing that identity is a factor that legislators include in the decision making progress.

\section{Identity And Legisltive Decision Making}

The majority of legislative decision making studies focused primarily on legislators during a time in which representatives were overwhelmingly White and male. Not only are gender and race rarely considered, but the idea of identity as a mediating force in decision making had not been articulated during the time in which much of the previous literature was written. It is possible that identities based on race and/ or gender and/or some other politically-relevant category influence legislative decision-making.

Various theories - such as informational, partisanship, institutional, identity-based - on why legislators make the decisions they do, assumes that legislators are rational actors. Most existing models of legislative decision making do not account for the role that intersectionality plays in 
representation. The dominant literature on legislative decision making does not include identity but instead posits that a host of external pressures influences legislative decision making (Bauer, Pool, and Dexter, 1963; Huber, 1989; Fiorina 1974; Kingdon, 1989; Matthews and Stimson 1970; Wolman and Wolman 1977). This type of literature has led Mayhew to conclude that scholarship has failed to provide a concrete link between who legislators are and what they do (1974). Legislative decision making scholarship that does not include identity can be best organized around models of necessary factors for effective legislative decision making. Succinctly, the scholarship reviewed above contends that representation representatives behave the way they do because of external pressure.

Perhaps Mansbridge's discussion of gyroscopic representation, the idea that "representatives look within for guidance," $(2003,520)$ is closest to the idea that descriptive characteristics can provide predictability of how a legislator will act above and beyond party identification. This theory of representation purports that legislators include internal factors in their representational capacities. In gyroscopic representation, representatives place their attitudinal identity with their constituents to derive from their own experience conceptions of interest and principles to serve as a basis for their action. However, unlike Mansbridge's contention that a legislator's own principles and beliefs guide representational actions, I contend that identity influences representatives' legislative decision making. Identity foregrounds experiences that lead legislatives to develop their policy preferences as well as their principles and beliefs. Even theories that explicitly focus on the role of identity fail to appreciate the dynamism and nuances within identity or the multiplicity of a race/gender identity.

While we know that identity impacts political representation, we have little knowledge on how representatives' identity impact their legislative decision making process. Furthermore, much of what we know about the effects of legislators identity's on the legislative decision making process is based on only minorities or women. This study is the first to use a comparative analysis of how Black women and men as well as White women and men use their identity in the legislative decision making process for both Whites and Blacks and men and women. Thus this study seeks to examine if an expressed commitment to identity influences legislative decision making. Next, do Black women, Black men, White women, and White men talk similarly or differently about race and gender in the legislative decision making process? This article examines how legislators articulate the relationship between identities and the way legislators bring their identity to bear on legislative decision making. 


\section{Case Selection and Methods}

Due to the small number of African American women serving in state legislatures across the country, I chose to study the Maryland state legislature because of its comparatively high number of African American women state legislators during the 2009 legislative session (20, distributed among 15 delegates and 5 senators). The Maryland legislature is highly professionalized (high salary, large staff, longer session) and is comprised of part-time representatives who dedicate an annual ninetyday period to law making. Maryland's political culture is regarded as akin to that of a business because individual legislators broker deals and orchestrate political favors (Elazar 1972). While the party structure is highly organized, legislators have the ability to act as individuals, especially in policy areas in which they have specialized knowledge (Smooth 2001). Maryland's short legislative session requires a structure that facilitates lawmaking at a relatively quick pace because lawmakers have only 90 days to act on over 2,300 pieces of legislation, including the state budget. As a result, Maryland has a highly organized committee structure, and leaders in both chambers are responsible for assigning other members to serve on committees.

The General Assembly includes 47 senators and 141 delegates elected from 47 districts. The multi-member districts are comprised of four representatives - one senator and three delegates. The multi-member district structure is ideal for examining the effects of race and gender identity on legislative decision making, since many of the legislators represent the same constituency - which is particularly true of the African American Maryland state legislators as they represent majority Black districts located in Baltimore City, Baltimore County, or Prince George's County, $\mathrm{MD}^{3}$. As a result, I can differentiate constituent wishes as a

3 According to the 2010 Census, of the 5,773,552 residents in Maryland, 29 percent are African American, 58 percent are White, 5 percent Asian, and 8 percent Hispanic. The African American women legislators represent districts with a majority, or near majority, of Black constituents. They primarily represent districts in Baltimore City, Baltimore County, and Prince George's County (a suburb of Washington, DC). According to the 2010 Census, Baltimore County is 64 percent White, 26 percent Black, 5 percent Asian, and 4 percent Hispanic. Its population is 805,029 . While Baltimore County is considered suburban, the towns and municipalities closest to Baltimore City, located in Baltimore County, resemble inner cities. The 2010 Census counted 620,961 Baltimore City residents. Demographically, Baltimore is a majority-minority city with 63 percent Blacks, 29 percent White, 2 percent Asian, and 4 percent Hispanic. Baltimore City is commonly spoken of as having two sections: east and west. East Baltimore is a largely Black community with low-income neighborhoods. West Baltimore is more diverse, its population ranging from middle- to upper-class African American neighborhoods, low-income White neighborhoods, Jewish neighborhoods, and pockets of Black poverty. Baltimore City has also enjoyed two African American women mayors: Sheila Dixon (2007-2010) and Stephanie Rawlings-Blake (2010-present).

As of 2010, Prince George's County, MD, has a population of 863,420 and is the wealthiest county with an African American majority in the United States (Howell 2006; Chappell 2006). 
factor in legislative decision making from other internal factors, such as identity, that drive legislators' behavior.

The data for this project comes from fifty one in-depth, semi-structured and open ended interviews that I conducted with Democratic ${ }^{4}$ Maryland state legislators during the 2009 legislative session. Weiss (1994) claims that interviews enable researchers to learn about the settings and people that may be unfamiliar and thus provide a window to understanding social processes in more depth. Legislators were faxed and emailed with a letter of request to interview on university letterhead. The letter broadly outlined the project and asked legislators to talk about the decision making process during a fifteen minute interview. The in-person interviews were conducted March 11, 2009 to March 20, 2009. Additional phone interviews were conducted through June 30 and July 2, 2009. However, the majority of the interviews took place in person in the Maryland state legislature. All interviews were on the record and lasted between eleven minutes to an hour ${ }^{5}$. The majority of the interviews were twenty minutes. I took detailed notes on every interview. The interviews were conducted in various legislative settings to provide for the legislator's schedule and accessibility. Most interviews were conducted in the legislator's office; however several were conducted in committee meeting rooms and a few were conducted with legislators as they walked to or from meetings.

I conducted interviews with all twenty of the African American women serving in the Maryland legislature. In addition to the African American women legislators, I also interviewed a convenience sample of their Democratic colleagues based on gender and race. Interviews were conducted with five White women, thirteen Black men, nine White men, one Latina, one Latino, and two Asian American women ${ }^{6}$. During the interviews, legislators were asked a set number of questions that covered their district characteristics, legislative history, institutional influence,

The county is currently 19 percent White, 64 percent Black, 4 percent Asian, and 15 percent Hispanic. Fifty-four percent of the county's firms are owned by African Americans and the median income is $\$ 70,647$. The county is devised into five sections: North County, Central County, the Rural Tier, the Inner Beltway, and South County. The Inner Beltway is majority African American, Central and North County have a large population of Blacks as well. Bowie, the county seat located in Central County, is 48 percent White.

4 Because all the African American women legislators were Democrats, I only interviewed members of this party. This allowed me to control for partisan ideologies of ten associated with a legislator's race and gender, thus avoiding distortions caused by partisan politics that might undermine the reliability of comparisons made along racial/ethnic and gendered lines. Controlling for party identification also allowed me to highlight intragroup differences.

5 While I informed the legislators that their interviews were "on the record," I have removed names from the quotations due to the candid nature with which some legislators engaged me in conversation.

6 Because of their small numbers in the Maryland state legislature, I have removed other legislators of color from this analysis. 
policy preferences, perception of identity and politics, and two specific bills: Religious Freedom and Protection of Civil Marriage and Financial Exploitation of the Elderly. Legislators were asked to explain the role that identity plays, if any, in the legislative decision making process. Because the interview questions provided for open ended answers the legislators were able to express themselves and narrate their stories to me.

This study utilizes qualitative techniques rather than quantitative methods in order to fully investigate the nuances in how identity mediates the legislative decision-making process. Additionally, quantitative techniques are "devised to reveal uniformities of behavior are by design insensitive to difference, treating anything that deviates from the norm as an outlier or anomaly" (Hawkesworth 2003, p. 532). Sophisticated statistical methods are insufficient to examine the interaction effects of race, gender, and generation since they require large data sets. Standard social science methodological techniques that attempt to isolate the effects of gender by controlling for race/ethnicity by controlling for gender are at odds with any effort to trace the complex interactions of race and gender in an organization (Spellman 1988, 103). Next, dummy variables assume static categories of analysis that do not reveal the multi layered effects of intersecting identities that are embedded within categories such as race or gender. This explanatory variable fails to acknowledge the complexity within categories (Junn and Brown, 2008).

In the sections that follow, I provide legislators' narratives on the impact of identity on the legislative decision making process. All legislators were asked "Do you think your identity plays a role in the legislative process? If so, how?"7 This open ended question allowed the state legislators to narrate their experiences in their own words and permit adequate answers to complex issues. Lawmakers were able to answer in detail and can qualify and clarify responses, permit creativity, self-expression, and richness of detail to reveal the legislator's thinking process and frame of reference.

\section{Identity and Legislative Decision Making}

\section{African American Women State Legislators}

The Black women legislators in this study invoked multiple identities, often simultaneous and intertwined identities, in explaining how identity plays a role in the legislative process. This indicates that for Black women legislators' race, gender, and other relevant categories of difference are often mutually constitutive. Almost all of the Black women interviewed claimed that there are times when identity influences legislative decision making.

\footnotetext{
7 See Appendix for interview protocol
} 
The African American women in this study invoked identity in two distinctive ways to explain its role in the legislative process. For example, repeated comments from legislators illustrated that they prioritized a particular part of their identity, depending on the legislative context. Other Black women legislators asserted that they cannot prioritize aspects of their identity. These legislators were unable to parse the components of their identity. For example, a Black woman delegate claimed that there are times when parts of her identity influence how she interprets legislation:

It [identity] probably contributes to but is not the only factor in how I feel about legislation. It would be difficult for me to tease out which parts of me because I am a Black woman and I am from the Midwest, I'm a mother. So which part of me is it that? (African American woman delegate, 12 March 2009, personal interview)

This delegate's response indicates that she uses an additive approach to understanding her identity. The additive model-one that posits that race and gender are mutually reinforcing-theorizes that two or more disadvantaged identities can be brought together if the subject experiences two or more distinct forms of discrimination in tandem (Gay and Tate 1998; King 1988). This African American woman delegate recognizes the importance of using her identity, when applicable, in the legislative process. She stated that she draws on different aspects of her identity in the legislative decision making process, but sees her identity as a sum of multiple parts, not one based on interlocking identities.

In articulating the trilogy of race, class, and gender as social locations that inform her identity as well as her experiences, another Black women legislator reported that her positionality is more or less salient depending on context. This Black woman delegate concurred:

Absolutely, absolutely. [Identity matters] because I have a different experience. If I did not bring my experience here I don't think I would be doing a service to the entire state of Maryland. I don't make decisions based on my race and gender, I bring an understanding that's reflected of my race and gender. . .. [In certain situations] I feel my gender more here or my race more here or my class background there. (African American woman delegate, 20 March 2009, personal interview)

Here, this delegate also uses an additive approach to including her identity in the legislative decision making process. This delegate indicates that she sees her experiences as filtered through her identity. She draws on these experiences in her legislative work. Her response prioritizes 
one identity over another but incorporates the multiplicity of identity in some aspect. These women favor an additive approach to politics; they view the totality of their identity as composed of separate and individual parts that combined to make them who they are.

\section{Racialized Gender Politics}

Next, indicating that a gendered perspective is necessary to fully understanding the legislative decision making process for African American state legislators, I heard recurring statements from legislators on the differences of both style and substance between Black men and women legislators. A Black woman senator argues that Black women display some dissimilarity in legislative style to Black men which is based on gender difference.

I don't think we (i.e. African American men and women) view legislation completely differently from one another. I think this is the issue, I think Black men in many instances - in terms of the legislative process - see the same things that we do but they are not as vocal or outspoken as Black woman are. (African American woman senator, 18 March 2009, personal interview)

This African American woman senator illustrates how belonging to two identity groups is useful in the state legislature. Providing an example of how Black women senators were more vocal on discussing racial disparities in criminal sentencing codes, this African American woman senator presented an example of Fraga et al's (2005) theoretical advancement of strategic intersectionality. This Black woman senator's combination of both her race and gender positions her to build cross-group coalitions which consequently enabled her to obtain greater levels of legislative success. Because of her gender, she may be viewed in a more favorable or less hostile/confrontational than their co-ethnic men around issues that disproportionately effect Black men. Further, Fraga et. al. argue that women's feminine attributes soften them and makes them more approachable than their co-ethnic males. Perhaps the Black women legislators, like the Latinas in Fraga and colleagues' study, were allowed a space to discuss racial disparities that their male counterparts were unable to.

Another Black woman delegate agreed that her identity brings a different viewpoint to legislating than those of her colleagues. As a result of her identity as a Black woman, she emphasizes that she can see things differently because of her experiences than her male colleagues of all races. "If I was a White male who may be a little chauvinistic, I would have a different viewpoint as opposed to a female of color. As a Black woman, you can relate to more people who are different from you as opposed to someone that were of another particular gender. So yes, my 
identity influences how what do in Annapolis - how I legislate." (African American woman delegate, 16 March 2009, personal interview)

Identity influences several aspects of political representation for the Black women legislators in this study. These Black women legislators articulated that identity influences their understanding of legislation as well as demarcates differences between how Black men and women view legislation. African American women legislators in the Maryland state legislature in 2009 combine both race and gender in their understanding of identity, which is similar to some tenets of Black feminism. Because race and gender are salient identities, which are of ten interwoven, for Black women it is likely that the this group of legislators cannot parse out their gendered identity, or are reticent about describing it in feminist terms without placing their actions in a racialized tone as well. This does not mean that Black women are not feminists; indeed, the Black women legislators express their gender identity in intersectional terms, noting specifically that their racial identity is inseparable from their feminist identity (Hurtado 1996).

\section{African American Men State Legislators}

In contrast to the African American women representatives, Black male legislators interviewed for this study frequently said that a gender identity is not salient in their decision making processes. When asked if their identity played a role in how they interpret legislation, the overwhelming majority of male African American legislators said that they relied solely on a racialized construction of identity. Specifically, the Black male legislators said that they do not think about gender in the legislative decision making process. One Black man delegate said "gender, no not as much. I'm kind of like a gender neutral person" (personal interview, 11 March 2009). Similarly another delegate said "I think gender has very little to do with how I interpret legislation" (African American man delegate, personal interview, 19 March 2009).

An African American male delegate provided an example of why gender does not influence his legislative thinking.

My race [influences my legislative decision making] more than anything else. I think race trumps gender. Although a lot of Black women didn't see it that way they were jumping up and down for Hilary Clinton and not Barack Obama [during the 2008 Democratic primaries]. But anyway, race influences how I interpret legislation. (African American man delegate, 13 March 2009, personal interview) 
These statements reflect that maleness is the unmarked gender category, the norm against which women are compared. This social construction $^{8}$ of gender reflects patriarchy and male privilege and a prevailing notion of Black male dominance within the African American community. The above quotes by the Black men state legislators in this study do not think in gendered terms illustrates the dominant role that maleness plays in society, even by men who are disadvantaged by their race. Additionally, these statements signal silences around conversations of gender differences among African American legislators as Black men legislators in this study do not view gender a salient identity.

\section{Non-Gendered Racialized Identity}

Both male and female African American legislators interviewed for this study articulated race as a governing structure through which they view the legislative decision-making process. They did not interrogate the construction of race but instead relied on the tangible effects of race in American society by working on legislative goals to benefit 'the Black community.' For the legislators in this study, there is a distinct Black community as well as certain proscribed notions of what it means to be Black. As a result, the legislators in this study view some aspects of their legislative agenda as distinctly helping African Americans.

African American legislators of both genders feel a commitment to represent the Black community, but it is only the Black men legislators in this study who refer to a solely racialized identity to articulate the ways in which identity mediates representation. For example, one Black man delegate finds that his very legislative purpose is centered on race. "I'm here to clearly represent the African Americans" (Black man delegate, personal interview, 16 March 2009). Black legislators in this study said that they bring a racialized understanding to the legislature because they have experienced struggles based on racial discrimination. This quote also exemplifies that race is a predominant identity for African American male legislators in this study. For example, one Black man delegate observed:

Yes [identity plays a role in the legislative process] because there is an understanding in the Black community that it will be very difficult for someone in the White community to understand. So there is a need for the Black Caucus in that regard to legislate on Black issues. How can you truly understand what's happening in our

8 The locations, discourses, and material relations that are historically, socially, politically, and culturally produced that are intrinsically linked to systems of domination (Frankenberg 1993) 
community if you don't know it, you haven't walked it? I'm not going into any Jewish community and say, "I understand exactly what you been through" because that would be a lie. And they can't come into my community and say I understand exactly what you are going through because that would be a lie. (African American man delegate, 19 March 2009, personal interview)

While African Americans are better of politically and economically today than they were in the past, studies indicate that Blacks still view racism as impeding their success to achieve full parity in American society (Hochschild,1995; Schuman et al, 1997; Smith et al, 2000; Sigelman and Welch, 1991). As a result, White racism dictates Blacks' experiences as well as outlook on social phenomena. A Black male delegate suggests that Blacks' experiences with racial discrimination cause African Americans and Whites to view the world differently. In detailing his experiences with racial discrimination in Annapolis, this African American male legislator explains that he believes he was racially profiled for driving an expensive car near the statehouse. This example, among other personal experiences with racism, leads him to believe that race based discrimination produces different experiences for Whites and Blacks which leads to different legislative priorities for legislators of different races.

Yes, I do view things differently from Whites. It's based on your environment and your surroundings and I bring that effect to legislation. They don't understand that "driving while Black" versus their driving while White, and they don't understand that "the Man" is going to pull me over. (African American man delegate, 20 March 2009, personal interview)

African American men legislators in this study comment on race devoid of gender when discussing the ways in which identity matters in the legislative process. Race identification may act as a first lens through which issues are evaluated in relationship to the hierarchy of interests, which prioritizes race over gender in the Black community (Mansbridge and Tate, 1992). A shared history of past and present race based discrimination - slavery, Jim Crow, de jure segregation, literacy tests, grandfather clauses, lynching, poll taxes, White primaries, discriminatory practices such as steering and blockbusting by realtors, redlining by banks and loan companies, de facto segregation, and racial profiling have reinforced African Americans' strong reliance on racial identification (Dawson, 1994). While there is racial solidarity with their co-racial/ 
ethnic men, minority women also struggle against patriarchy and sexism from their men.

\section{IDENTITY MATTERS . . . SOMEHOW}

\section{White women and men state legislators}

White men and women legislators interviewed for this study did not make explicit claims based on identity. Instead, they frequently posited that identity matters but were not ultimately convinced that it played a role in the legislative decision making process. A very small number of White legislators of both genders make use of their racial identity in the legislative decision making process differently than Black state legislators. Their racial categorization as White went without mention. In line with Ruth Frankenberg's (1993) contention that Whites do not see themselves as raced, none of the White state legislators in this study said that their racial and gendered identities were salient factors in the legislative decision making process. Namely, the categories of White, male, and middle-class are not contested categories of identity. Instead, those are neutral positions to which all others are compared. As a result, the majority of White legislators in this study did not make explicit reference to their racial or gendered identity as a factor they include in legislative decision making. Thus there is no analog to the claims of racial identity in mediating legislative behavior for Whites as there are for Black members of the Maryland legislature.

When asked about identity, the White women and men legislators in this study predominately replied that it operates as an unknown or intangible variable that may or may not influence legislative decisions. For example, one White woman delegate observed "I'm sure it does. It must. Everyone's identity must have an impact on legislation. But for me, I'm not sure what it is" (White woman legislator, personal interview, 18 March 2009). Without mentioning race and/or gender, the White legislators agree that identity influences the legislative decision making process. For example, a White man delegate suggests "all of things are part of who you are, so, to the extent that they make up who you are of course they are going to have an influence on how you see the world. Legislation is how you see the world" (White man delegate, personal interview, 12 March 2009). Similarly, a White woman delegate finds that experience matters in the legislative process. "Yeah, I think for all of us our practical experience and what you bring to this job absolutely makes a difference" (White woman legislator, personal interview, 20 March 2009). The White legislators rarely detail how his or her identity matters in racialized or gendered terms.

However, there are two White legislators who made explicit connection to their racial and gendered identities when asked how their iden- 
tity may influence the legislative decision process. One White male delegate notes that he cannot escape his Whiteness or class status. Additionally, this White male delegate does not place a direct connection to his identity and experiences to the legislative decision making process, but acknowledges his racial and class status have impacted his life experiences.

Certainly I can't separate the way I view things from the experiences that I have had. To the extent that the experience that I have had are related to those identity factors then it's connected, not a direct connection. But I can't escape my own Whiteness and I can't escape my own middleclass upbringing. (White man delegate, 14 March 2009, personal interview)

This legislator's recognition of his own identity is telling, as he is the only White legislator to make direct mention of his race. Only one White woman delegate explicitly mentioned her gender as impacting her legislative decision making process. When asked if her identity affects the considerations she brings to legislation this delegate said that her identity as woman matters in the legislative process. "I've always had a statement 'all bills are women's bills.' But, I would say that because I'm a woman, I obviously have bias towards fairness with women's issues" (White woman delegate, personal interview, 17 March 2009). She was the only delegate to directly mention her identity as a factor in why she champions gender and women's issue bills. As a White woman, she may be able to see her gender as more salient because she is advantaged by her race. The other White women legislators interviewed for this study did not express a rhetorical commitment to women's issues ${ }^{9}$. The Black and White male legislators do not explicitly mention women's issues either. This finding further strengthens arguments in the women and politics literature that illustrates that women legislators are more likely to represent women's interests.

Rather than citing race or gender as salient identities, other White legislators in this study contend that their profession chiefly influences their legislative decision making. For example, a White woman delegate noted that she believes "we all bring our own individual perspective but, for instance I work a lot on family law and domestic violence legislation because I practiced family law" (White woman delegate, personal interview, 19 March 2009). This White woman legislator directly connects

9 The exception is a long time feminist delegate who was one the first women to be elected to the Maryland state legislature. Her discussion of women's issues is within the context of domestic violence legislation as a feminist cause. 
her policy preferences to her profession as a family lawyer ${ }^{10}$ yet she does not connect her gender to these traditionally women's interest. Likewise, another White woman delegate who is also an attorney insisted:

I would venture to guess you can't divest yourself entirely of your background in making those decisions. Certainly my work experience definitely makes a difference in the way I see and my ability to see certain aspects of legislation. (White woman delegate, 11 March 2009, personal interview)

A White man delegate and fellow attorney additionally explained:

I simply think it's based on professional experience. I'm an attorney. Your past observations and legislative history in review of the law [matter in legislative decision making]. (White man delegate, 18 March 2009, personal interview)

These above quotes by three White state legislators in this study indicate that their profession as attorneys carries weight in their decision making process. Indeed, knowledge of the law impacts the development of public policy. This connection is closely related to the dominant legislative decision making literature that posits that legislators relay on policy experts, themselves or others, to influence their position on a policy (Kingdon 1989; Poole and Daniels, 1985; Poole and Rosenthal, 1991).

Two White legislators in this study said that identity, in any form, does not influence their legislative decision making. For example, a White man delegate said "I hope not" (White man delegate, personal interview, 18 March 2009) while a White woman delegate said "I don't think so, no" (White woman delegate, personal interview, 11 March 2009). These were the only legislators who outright said that identity does play a role in the legislative decision making process. But taken as a whole, the White legislators in this study illustrate that African American legislators are more likely to use their racial and gendered identities to assist in the legislative decision making process.

\section{CONCLUSION}

While Black legislators interviewed for this study believe that racial identity is relevant in their decision making processes, White members of the Maryland state legislature had difficulty deciding whether their identities mattered and had even more trouble articulating how or why they did. The differences in the data are striking. In this regard, the state- 
ments provided by legislators in this study offer an important intervention for the literature on legislative decision making to show that legislators often include identity as a factor in the legislative process.

The majority of White women and men legislators in this study agree that identity impacts the legislative decision making process yet are unable to articulate precisely how race, gender, or an intersectional approach is useful to them. In addition, the White women and men legislators interviewed for this project referenced their professional identity as a factor in the legislative decision making process. Black women or men state legislators in this study did not mention their profession as a factor that influences legislative decision making. This finding points to a difference in the literature since Black women and men legislators do not mention profession by means of policy specialization as a factor they include in legislative decision making (Witko and Friedman, 2008). While professional identity leads to experiences that may influence legislative behavior, the Black women and men legislators in this study do not highlight its role in legislative decision making. Perhaps African American women and men legislators see race as fundamental to their identity, and Black women see race/gender as a critical component of their identity, however professional occupation is not explicitly connected to legislative decision making for Black legislators in this study. White legislators may not be as invested in a racialized identity because Whiteness is an unmarked and unnamed category in America (Frankenberg 1993, Doane and Bonilla-Silva, 2003). As a result, these legislators may identify with an occupational identity since acknowledging Whiteness would entail critically reflecting on the social position of dominance that White people occupy in our society. Finally, both Black men and women legislators agreed that either a racial, gendered, or intersectional identity mattered in the legislative process but only some of the White legislators in this study said that identity did not matter at all.

Specifically, the Black women legislators provided examples of when and how they include identity in legislative decision making through utilizing their experiences to better understand legislation; providing legislative examples that center on race/gender identity on their legislative agenda and/or articulate their legislative priorities. Indeed, taken as a whole the Black women legislators interviewed for this study had the most encompassing view of identity. They expressed a rhetorical commitment to the ways in which identity influences the legislative decision-making process. They also discussed identity in a nuanced manner either taking an additive approach or an intersectional approach to identity politics.

This essay has demonstrated that the role of identity in representation is readily seen in African American women and men Maryland state 
legislators. African American women legislators in Maryland articulate or describe an intersectional identity as a meaningful and significant component of their work as representatives. More specifically, Black women legislators use their identity to interpret legislation differently due to their race/gender identities. Rhetorically, Black women legislators in this study expressed different concerns, challenges, and advantages in the legislative process based on their social positioning. The majority of Black women Maryland state legislators find that the legislative decision making process is informed by both their race and gender. This suggests that race and gender play a profound role in African American women's legislative decision making.

\section{REFERENCES}

Alcoff, L. M., Hames-Garcia, M., Mohanty, S.P., and Moya, P. (2006). Identity Politics Reconsidered: Palgrave McMillan.

Bauer, Raymond, Ithiel de Sola Pool,, and Lewis A. Dexter. 1963. American Business and Public Policy The Politics of Foreign Trade. Chicago: Aldine.

Bratton, Kathleen A., and Kerry Haynie. 1999. Agenda Setting and Legislative Success in State Legislatures: The Effects of Gender and Race. Journal of Politics 61:658-679.

Crenshaw, K. W. (1988). Race, Reform, and Retrenchment: Transformation and Legitimation in Antidiscrimination Law. Harvard Law Review, 101 (7), 1331-1387.

Dawson, Michael. Behind the Mule: Race and Class in African-American Politics. Princeton: Princeton University Press, 1994

Doane, Ashley W. and Eduardo Bonilla-Silva, ed. 2003. White Out: The Continuing Significance of Racism. New York: Routledge.

Dovi, Suzanna. 2002. Preferable Descriptive Representatives: Will Just Any Woman, Black or Latino Do? American Political Science Review 96:729-743.

Elazar, D. J. (1972). Federalism: A View from the States (Second ed.). New York: Harper and Row.

Fenno, Richard. 2003. Going Home: Black Representatives and their Constituents: University of Chicago Press.

Fiorina, Morris. 1974. Representatives, Roll Calls, and Constituencies. Lexington, Mass.: DC Health, Lexington Books.

Fraga, Louis Ricardo, Valeria Martinez-Ebers, Ricardo Ramierez,, and Linda Lopez. 2005. "Gender and Ethnicity: The Political Incorpora- 
tion of Latina and Latino State Legislators". In Inequality and Social Policy Seminar. John F. Kennedy School of Government.

Frankenberg, Ruth. 1993. White women, race matters: the social construction of whiteness. London: Routledge.

Gay, Claudine., and Katherine Tate. (1998). Doubly Bound: The Impact of Gender and Race on the Politics of Black Women. Political Psychology, 19 (1), 169-184.

Hawkesworth, Mary. 2003. Congressional Enectments of Race-Gender: Toward at Theory of Race-Gendered Institutions. American Political Science Review 97 (4):529-50.

Hochschild, Jennifer L. 1995. Facing up to the American dream: Race, calss and the soul of the nation. Princeton, NJ: Princeton University Press.

Huber, Oswald. 1989. Information-Processing Operators in Decision Making. In Process and Structure in Human Decision Making, edited by H. M. Svenson and Ola. New York: John Wiley.

Hurtado, A. 1996. The Color of Privilege: The Blasphemies of Race and Feminism. Ann Arbor: University of Michigan Press.

Junn, J., \& Brown, N. (2008). "What revolution? Incorporating intersectionality in women and politics". In K. B. Christina Wolbrecht \& B. Lisa (Eds.), Political Women and American Democracy. New York: Cambridge University Press.

King, Deborah. 1988. "Multiple Jeopardy, Multiple Consciousness: The Context of Black Feminist Ideology,. Signs: Journal of Women in Culture and Society Autumn:88-111.

Kingdon, John. 1989. Congressmen's Voting Decisions. 3rd ed. Ann Arbor: University of Michigan Press.

Mansbridge, Jane. 1999. Should Black Represent Blacks and Women Represent Women? A Contingent 'Yes'. The Journal of Politics 61 (3):628-57.

- 2003. Rethinking Representation. American Political Science Review 97 (4):515-528.

Mansbridge, Jane., and Katherine Tate. 1992. Race Trumps Gender: The Thomas Nomination in the Black Community. PS: Political Science and Politics 25 (3):488-93.

Matthews, Donald, and James Stimson. 1970. "Decision-Making by U.S. Representatives". In Political Decision Making, edited by S. S. Ulmer. New York: Van Nostrand Reinhold. 
Mayhew, David. 1974. Congress: The Electoral Connection. New Haven, CT: Yale University Press.

Phillips, Anne. 1995. The Politics of Presence. Oxford: Clarendon Press.

Pitkin, H. (1967). The Concept of Representation. Berkeley, CA: University of California Pres

Poole, Keith T. and Howard Rosenthal 1984. The Polarization of American Politics. Journal of Politics 46:1061-79.

Poole, Keith T. and R. Steven Daniels. 1985. Ideology, Party and Voting in the U.S. Congress, 1959-1980. American Political Science Review 79:373-99.

Puwar, Nirmal. 2004. Space Invaders: Racem Gender and Bodies Out of Place. Oxford: Berg Publishers.

Rosenthal, Cindy Simon. 2002. Women Transforming Congress. Norman: University of Oklahoma Press.

Sanchez, R. (2006). "On A Critical Realist Theory of Identity”. In M. H.G. S. P. M. Linda Martin Alcoff \& M. L. M. Paula (Eds.), Identity Politics Reconsidered. New York: Palgrave McMillan.

Schuman, H., C. Steeh, L. Bobo, and M. Krysan 1997. Racial Attitudes in America: Trends and Interpretations Cambridge, MA: Harvard University Press.

Sigelman, L., and S. Welch 1991. Black American's Views of Racial Inequality: The Dream Deferred. New York: Cambridge University Press.

Simien, E. 2006. Doing Intersectionality Research: From Conceptual Issues to Practical Examples. Political and Gender 3 (2).

Smith, W.R., D. Tomaskovic-Devey, M. Mason, M.T. Zingraff, C. Chambers, P. Warren, and C. Wright. 2000. Driving While Black": Establishing a Baseline of Driver Behavior by Measuring Driving Speed and Demographic Characteristics. In Unpublished Manuscript. North Carolina State University, Raleigh.

Smooth, W. G. 2001. African American Women State Legislators: The Impact of Gender and Race on Legislative Influence, Dissertation Services, UMI.

. 2006. Intersectionality in Electoral Politics: A Mess Worth Making. Politics and Gender 2 (31):400-414.

Spellman, Elizabeth. 1998. Inessential Woman: Problem of Exclusion in Feminist Thought. Boston: Beacon Press. 
Swers, Michele L. 2001. Research on Women in Legislatures: What Have We Learned, Where are We Going? Women and Politics 23 (1-2):167-85.

- 2002. The Difference Women Make. Chicago: University of Chicago Press.

Swain, C. M. (1993). Black Faces, Black Interests: The Representation of African Americans In Congress. Cambridge, MA: Harvard University Press.

Tate, Katherine. 2001. The Political Representation of Blacks in Congress: Does Race Matter? Legislative Studies Quarterly 26:623-38.

Weiss, R. 1994. Learning From Strangers; the Art and Method of Qualitative Interview Studies. New York: The Free Press.

Witko, Christopher and Sally Friedman. 2008. Business Backgrounds and Congressional Behavior. Congress \& The Presidency 35 (1):7186.

Wolman, Harold L., and Dianne M. Wolman. 1977. The Role of the U.S. Senate Staff in the Opinion Linkage Process: Population Policy. Legislative Studies Quarterly 2:281-293. 
APPENDIX

Interview Protocol

1) Can you describe your district, your constituents, and the people you represent for me?

a. Can you talk specifically who the people are in your district?

2) What particular groups or people in your constituency that was particularly important in getting you elected?

a. Particular groups/people/organizations - not necessarily in your district that were important in getting you elected?

3) Are there people in you district or your constituency who feel a special connection to you? Can you tell me about that?

a. Who are they?

b. Why?

c. Are there people in your constituency that you share a special connection with?

4) Do you think your background/ personal characteristics matters in how your constituency sees you?

5) Do you think your identity matters in how you see/interpret legislation?

6) Do you think your identity plays a role in the legislative process? If so, how?

7) In general, do you believe identity effects or matters in the legislative process?

8) What pressures, if any, do you feel your personal identity brings to bear on legislative decision making?

9) Thinking of where you consider yourself within this body where would you place yourself on a scale from 1-7? Where 1 is at the margin of power and 7 is at the center, where do you feel you fit into this body?

a. Why?

10) How did you come to your position on this policy (HB 1055 or SB 565 - Religious Freedom \& Protection of Civil Marriage Act)?

a. How did you decide whether you were for or against it?

11) How if any, did your background/personal characteristics and experiences that influenced the position you took (will take) on HB 1055 or SB 565 (Religious Freedom \& Protection of Civil Marriage Act) preferences? 
12) How, if any, did your identity (specifically - tailored to reflect the legislators racial and gendered make up) matter in this (HB 1055 or SB 565 -Religious Freedom \& Protection of Civil Marriage Act) policy context?

13) Do you represent marginalized groups?

a. If so, what are those groups?

14) What is your relationship with marginalized communities? (LGBT, incarcerated, drug users, etc.)

a. How close to feel to

b. Are there active LGBT groups in your constituency?

c. Do you feel responsibility to represent the LGBT community?

d. Did the LGBT community play an active role in your election

15) What is your relationship with the elderly community?

a. How close do you feel to the elderly?

b. Are there active elderly groups in your constituency?

c. Do you feel a responsibility to represent the elderly community?

\section{Demographic Questions}

16) What year were you born?

17) What is the highest level of education you have achieved?

18) What is your religious preference

19) Would you describe yourself as a born-again or Evangelical Christian?

20) Please indicate your combined family income
a. Less than $\$ 20,000$
b. $\$ 20,000-\$ 40,000$
c. $\$ 41,000-\$ 60,000$
d. $\$ 61,000-\$ 80,000$
e. More than $\$ 95,000$

21) What is your racial/ethnic background?
a. White
b. African American/Black
c. Asian
d. Hispanic
e. Native American
f. Multi-cultural

22) What is your political ideology?
a. Extremely Liberal
b. Liberal
c. Slightly Liberal 

d. Moderate, Middle of Road
e. Slightly Conservative
f. Conservative
g. Extremely Conservative
h. Don't Know, Haven't Thought

23) What is your marital status?

24) Is there anything that you would like to add

\section{Additional Framing Questions}

1) What would you rank amongst your top legislative accomplishments and why?

a. What are your biggest legislative priorities?

2) What are the significant political events that have shaped your politics?

3) What legislative issues do you have a personal interest? Why?

4) Do you think your background/ personal characteristics such as race, gender, class, generation, etc. matters in how your constituency sees you?

5) Do you think your background/personal characteristics such as race, gender, class, generation, etc. matters in the legislative decision making process?

a. How do these characteristics play a role in agenda setting and your policy priorities?

b. If yes, can you give me a legislative example of where your identity mattered?

c. How do these characteristics play a role agenda setting and your policy priorities?

6) If you were born of a different race, gender, generation, and/or class, how different would you be?

a. Do you believe that difference would play a role in how you legislate?

b. Which personal traits manifest themselves in congressional behaviors?

7) Do you think different groups of legislators (such as racial/ ethnic minorities, women, etc) bring different things to the legislature?

a. What are the specific differences?

b. Can you tell me a story that illustrates those differences?

8) Among your colleagues do you think that ethnicity, race, gender, class, etc. effects bill sponsorship, legislative priorities, and their decision making? 
9) Do you see differences between male/female, women of color, and/or racial/ethnic minorities and majorities' legislative agenda?

a. What are they?

b. When are you most likely to be aware of those differences?

c. Can you tell me a story that illustrates those differences?

10) How important to you is it that you represent the interests of people with similar backgrounds or personal characteristics to yours?

11) In general, do you believe identity effects or matters in the legislative process?

12) Can you provide a legislative example of a time you believed your identity may have influenced your understanding of a particular bill? 